\title{
Yersinia rohdei
}

National Cancer Institute

\section{Source}

National Cancer Institute. Yersinia rohdei. NCI Thesaurus. Code C86862.

A species of facultatively anaerobic, Gram negative, rod shaped bacteria in the phylum Proteobacteria. This species is positive for urease, ornithine decarboxylase, pyrazinamidase and citrate, motile and negative for lipase, lysine decarboxylase, oxidase, and indole. It is able to ferment arabinose, cellobiose, melibiose, raffinose, sorbitol, trehalose, and sucrose but not inositol, or rhamnose. Y. rohdei is found in aqueous environments and animal feces and is not a known human pathogen. 